Article

\title{
Supply Chain Governance Mechanisms, Green Supply Chain Management, and Organizational Performance
}

\author{
Sang M. Lee ${ }^{1}$ and Donghyun Choi ${ }^{2, *}$ \\ 1 Department of Management, College of Business, University of Nebraska-Lincoln, Lincoln, NE 68588, USA; \\ slee1@unl.edu \\ 2 School of Air Transportation and Logistics, Korea Aerospace University, Goyang 10540, Korea \\ * Correspondence: dchoi@kau.ac.kr
}

Citation: Lee, S.M.; Choi, D. Supply Chain Governance Mechanisms, Green Supply Chain Management, and Organizational Performance. Sustainability 2021, 13, 13146. https:/ / doi.org/10.3390/su132313146

Academic Editor: Tarik Aouam

Received: 30 October 2021

Accepted: 25 November 2021

Published: 27 November 2021

Publisher's Note: MDPI stays neutral with regard to jurisdictional claims in published maps and institutional affiliations.

Copyright: (c) 2021 by the authors. Licensee MDPI, Basel, Switzerland. This article is an open access article distributed under the terms and conditions of the Creative Commons Attribution (CC BY) license (https:/ / creativecommons.org/licenses/by/ $4.0 /)$.

\begin{abstract}
While firms understand that implementing green supply chain management (GSCM) is important, they seem uncertain about how to manage their green initiatives by looking beyond their own facilities. Building a green supply chain requires the participation of all partner firms across the supply chain. However, partner firms are different in size, situation, capabilities, and even industries. Thus, encouraging them to participate in green initiatives is difficult. Many small and medium enterprises (SMEs) hesitate to comply with green initiatives as they require a substantial amount of investment. This study empirically examines the causal relationship between the partnership governance mechanism and the success of GSCM. Based on transaction-cost economics theory (i.e., opportunism) and relational perspectives (i.e., trust) as the theoretical background, this study found that governance mechanisms between suppliers and manufacturers are positively related to GSCM performance. It showed that formal governance is important in the process-management side, while relational governance is critical for sharing knowledge in GSCM. The implications of the study results provide strategic insights on how the choice of governance mechanism affects GSCM performance and thus a firm's competitiveness.
\end{abstract}

Keywords: green supply chain; governance mechanism; innovation; green process; performance

\section{Introduction}

Many countries around the globe have enacted environmental regulations to minimize harmful output and operational processes. Thus, many businesses have joined the "green movement". This movement emphasizes the importance of green supply chain management (GSCM), which has brought a great deal of risk to those firms that fail to manage their suppliers for green operations [1]. In today's dynamic market environment, especially in the current COVID-19 pandemic crisis, collaboration between original equipment manufacturers (OEMs) and suppliers for developing and sustaining an effective supply chain is imperative, as it is aimed at not just reducing costs through process innovation but also becoming environmentally friendly to fulfill their social responsibilities [2-5].

A growing number of organizations realize that, to simultaneously achieve their environmental goals and competitiveness, they need to manage their supply chains with green initiatives looking beyond their own facilities. For example, the Responsible Business Alliance (RBA) has been introduced to encourage suppliers to participate in green supply chain initiatives [6]. The firms participating in this initiative include such global firms as Apple, Cisco, Dell, Hitachi, Intel, Microsoft, Sony, and Xerox. This program requires suppliers to define and deploy environmental management systems, measure the environmental impact of their operations, establish goals to improve their green performance, publicly disclose their metrics and results, and "cascade" these requirements to their own suppliers.

To participate in green supply chain management, suppliers need to invest in environmentally friendly equipment, processes, and human resources training. Suppliers, typically small- and medium- sized enterprises (SMEs), face much greater risk than their large buyer 
organizations when they are asked to invest in environmentally friendly systems [7]. The exchange hazards embedded in transaction-specific investments could be better managed if the right governance mechanisms are in place. Transaction-specific investments are those specialized to the OEM-supplier relationship. For example, a supplier might invest in specialized processes or equipment to produce customized or required components for an OEM that requests green process engineering. However, green transaction-specific investments can be costly for suppliers, because such investments do not create value in their other relationships. If an OEM decides to terminate the partnership, a supplier could have difficulty recouping the loss of its investments. Thus, suppliers might hesitate to invest in green systems.

Previous studies have indicated how firms engage in green supply chains and how this can increase profit [8-11]. However, there is a paucity of empirical studies that address the question of how OEMs can motivate their suppliers (e.g., SMEs) to implement GSCM systems under the right supply chain governance mechanism [12,13]. In addition, studies have analyzed the governance mechanism as control between buyers and suppliers for achieving a competitive advantage. However, not all collaboration efforts would result in successful outcomes, since different supply chain governance mechanisms deliver different signals to partners, because a possible mismatch between the supply chain governance mechanism implemented and the purpose relationship can harm the performance of green supply chain management.

The primary focus of this study is to investigate the following research questions: (1) How can choices between the formal transactional mechanism and the relational mechanism mitigate the risk of investing in green systems for the partners? (2) What is the impact of the chosen governance mechanism on organizational performance for the partners? This paper is organized as follows. In Section 2, we present a literature review and the hypotheses development. Section 3 discusses the method employed for the study, including data-collection and research methodology. In Section 4, we discuss the results of the study. Section 5 concludes the study with a summary, the theoretical and practical implications of the study results, the limitations of the study results, and the future research needs.

\section{Literature Review and Hypotheses Development}

\subsection{Exchange Hazard and Transactional Governance}

Transaction cost economics (TCE) posits that the costs associated with various interorganizational relationships embody the critical factor of determining the governance form. Partner organizations are assumed to have the potential to behave with opportunism [14]. According to TCE, credible economic commitments are necessary to sustain the interorganizational relationship. The high level of uncertainty in the relationship with a large buyer may cause suppliers to hesitate to invest in GSCM, because they would want an appropriate safeguard to protect them from risk [15]. The financial economic commitment by a supplier creates a locked-in relationship, which in turn promotes behaviors that ensure the continuance of the partnership [16]. Economic constraints such as the investment of specific assets tend to reduce the potential for opportunism by locking partners into an OEMs-suppliers relationship, as the expected long-term return of the relationship exceeds the potential short-term return of opportunism [17]. Thus, OEMs and suppliers may choose to have a comprehensive contract, a vertically integrated structure, or an arm's-length relationship when exchange hazards exist.

With more specified and formalized contracts, the hazard that each firm might experience would be minimized [18]. Furthermore, since the OEM firm may not be certain which partner will be opportunistic, the transaction cost for monitoring, modifying, and enforcing the terms of the contract would increase. In case of a high level of exchange hazard, an OEM firm would use a hierarchy structure with contracts that enable the firm to have tighter control over specific investments. Thus, the following hypothesis is proposed: 
Hypothesis 1 (H1). Exchange hazard is positively related to the need for a transactional governance mechanism.

\subsection{Trust and Relational Governance}

Trust has been considered as a factor that affects positive performance within the interorganizational relationship. In this vein, studies have suggested that justice can increase the acceptance of vulnerability because it signals how decision making will proceed over the long term [19].

Studies also support the notion that social-exchange relationships are based on trusting that other parties to the exchanges will fairly discharge their obligations in the long run [20]. High transaction costs and agency costs result when there is a low level of trust between partners, while studies observed low costs when a high level of trust was embedded between partners. An OEM-supplier relationship with high trust would allow the partners to communicate openly and the firms would be willing to take risks, because they would not be afraid to share information and would believe in the content of the information received. Thus, the following hypothesis is suggested:

Hypothesis 2 (H2). Trust is positively related to the development of a relational governance mechanism.

\subsection{Governance Mechanism and GSCM}

Studies have shown that a supply chain governance mechanism influences the relationship performance. The governance mechanism defines the specific processes or motivation that suppliers deploy to pursue the shared objective. This mitigates uncertainty between OEMs and suppliers in two different ways. The transactional governance mechanism provides guidelines that suppliers and OEMs should follow [21]. Based on a legal and institutional framework, the interorganizational relationship is controlled and monitored by partners. Green process management is the system that is institutionalized for internal environmental-management practices, and this enables the firm to meet the basic requirements for GSCM. Thus, the green process can be demonstrated to OEMs without relinquishing control of the asset. The pre-agreement disclosure characteristics of the green process make it easier for the firm to negotiate a mutually acceptable contract and specify the performance criteria that will form the basis of a formal mechanism [22].

Furthermore, unlike in knowledge-based collaboration, the firm can easily alter the specification of the green process with a contract. Since the green process is a standardized process (e.g., ISO 14001), it does not require partners to understand the terms that cannot be codified. Studies have found that the transactional mechanism is more effective at reducing opportunistic behavior and maintaining its agreements (e.g., the green process) [23] Therefore, the transactional governance mechanism is a more cost-effective way to manage the property-based assets. Thus, the following hypothesis is presented:

Hypothesis 3a (H3a). Transactional governance is positively related to the green process.

Knowledge sharing or transfer, a necessary condition for green innovation, is difficult to coordinate across firms because it needs to be embedded in the routines of the firm and is hard to specify by a contract [24,25]. In addition, it is impossible to include the intricacies of tacit-knowledge transfer in a contract, because tacit knowledge cannot be measured for its value or price [26].

However, few studies have investigated a formal contract as the governing mechanism to facilitate knowledge transfer. Formal contracts specify the obligations of both firms in the relationship to clarify the duties or tasks of each firm. They mitigate the uncertainty of returns from participating projects. Furthermore, when they play the role of a control tool, contracts may motivate participating firms to share explicit knowledge [27]. Thus, contracts may need to be specific and complete to create formal operating procedures that require the communication of explicit knowledge. The following hypothesis is proposed to explore this relationship: 
Hypothesis $\mathbf{3 b} \mathbf{b} \mathbf{H} \mathbf{3} \mathbf{b})$. Transactional governance is positively related to green innovation.

Relational governance influences the behavior of a firm and its performance $[28,29]$. Relational governance motivates the participating firms to be involved in the relationship to a greater extent than is necessary. Social exchange theory posits that trust is the factor that makes relational governance possible, allowing greater benefits of knowledge transfer, joint learning, and the sharing of risks and costs associated with exploring and exploiting opportunities [30].

Previous studies have found that collaboration between suppliers and OEMs enables the participating firms to leverage the resources and knowledge of their partners and customers by mitigating the 'fear that one's exchange partner will act opportunistically' [31]. When a firm believes that its partner will act in good faith and shirking will not occur, the firm tends to share its tacit knowledge more readily. Previous studies found that interorganizational relationships with trust positively affect innovativeness and supply chain performance [32-34]. These studies defined the core competency as the collective learning capability of the organization by coordinating production skills and integrating the dynamics of environmental changes. This mechanism facilitates participation in the green innovative process by restricting the opportunistic behavior. Thus, the following hypothesis is developed:

Hypothesis 4a (H4a). Relational governance is positively related to green innovation.

An interorganizational relationship that is based on trust not only facilitates knowledge transfer with interorganizational routines, but it also enables OEMs and suppliers to make mutual adjustments without having frequent renegotiations for contract changes [35]. This relationship with flexibility helps OEMs and suppliers have synchronized information on the status of the green process, so that they can resolve problems with agility. Studies have found that relational governance is more effective for seizing new opportunities, because the process is flexible, frequent, cooperative, mutually beneficial, and comprehensive [36]. Social exchange theory (SET) posits that two characteristics of the interorganizational context help us to understand the flexibility of the relationships between the firms. The first characteristic, which is trust, may influence the willingness of the partners to adapt to changing environmental demands through modifications. Secondly, the partners' dependence on the OEM-supplier relationship may have a positive impact on the longevity of the relationship by implementing what is demanded from the partners (e.g., the green process) [37]. The following hypothesis is proposed:

Hypothesis $4 \mathbf{b}(\mathbf{H} 4 \mathbf{b})$. Relational governance is positively related to the green process.

\subsection{Green Supply Chain Management and Performance}

Studies have found GSCM is positively related to financial profit and environmental performance [38-43]. A win-win argument suggests that the benefits of environmental management are larger than the costs and tighter regulatory standards will lead to superior performance [44]. Furthermore, participating in international standards such as ISO 14001 will positively affect organizational performance [45]. Studies have also argued that success in addressing environmental issues may help firms to reduce risk and, in turn, increase innovation and profitability [26,46].

The elimination of waste and the reduction of air emissions are noted as means to lowering costs. In addition, public announcements about a firm's green management practices positively affect its image as a socially responsible firm and its financial performance [47]. Green innovation has been proposed as a factor that positively influences organizational performance $[48,49]$. Thus, the following hypotheses are proposed:

Hypothesis $\mathbf{5 a}(\mathbf{H} 5 \mathbf{a})$. Successful implementation of the green process is positively related to the firm's financial performance. 
Hypothesis $\mathbf{5 b} \mathbf{b} \mathbf{H} \mathbf{b})$. Successful implementation of the green process is positively related to the firm's environmental performance.

Hypothesis 6a (H6a). Successful implementation of green innovation is positively related to the firm's financial performance.

Hypothesis $\mathbf{6 b} \mathbf{( H 6 b ) . ~ S u c c e s s f u l ~ i m p l e m e n t a t i o n ~ o f ~ g r e e n ~ i n n o v a t i o n ~ i s ~ p o s i t i v e l y ~ r e l a t e d ~ t o ~ t h e ~}$ firm's environmental performance.

Research model and hypotheses are described at Figure 1.

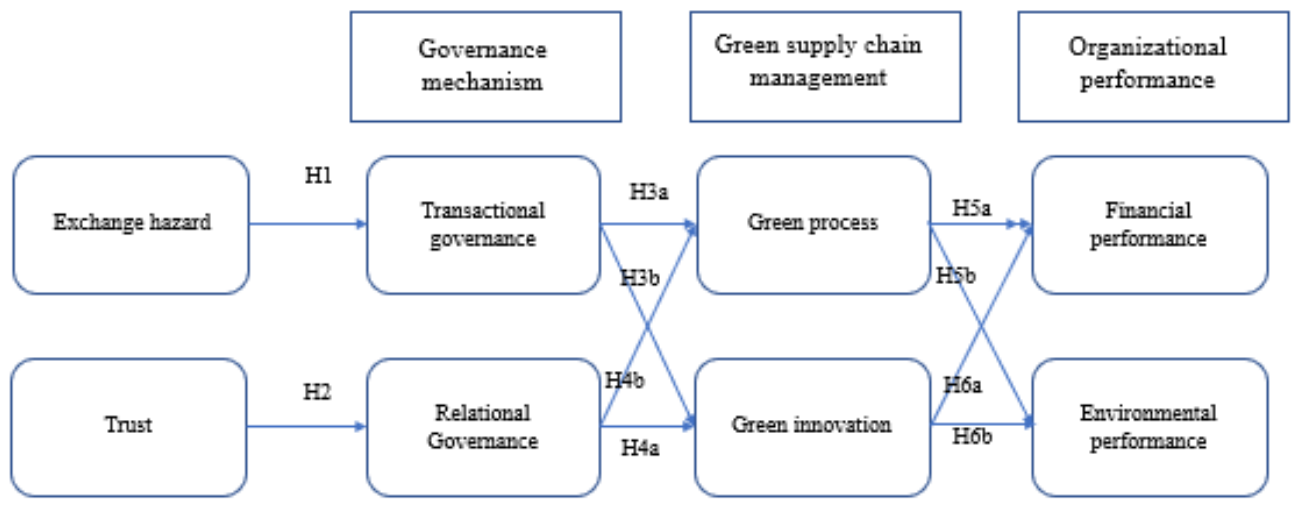

Figure 1. The research model with associated hypotheses.

\section{Research Methodology}

Survey and Data

The items used in the questionnaire were developed based on an extensive literature review (see Appendix A) and were measured on a seven-point Likert scale with anchors ranging from strongly disagree (1) to strongly agree (7), to ensure high statistical variability among survey responses. The questionnaire was developed through the double translation protocol [50]. The original version was prepared in English by the researchers of this study, mostly based on measurement items extracted from previous studies. Then, the questionnaire was translated into Korean by two bilingual operations management faculty. The Korean version was back-translated into English by two other bilingual SCM faculty. The two English versions had no significant differences. We pretested the Korean version of the questionnaire with 20 managers and professional staff of SCM departments. We made modifications and changes to clarify ambiguous parts of the questionnaire.

Copies of the questionnaire were distributed through Qualtrics, a well-established web-based survey service. Web-based surveys have received increasing attention in recent years, owing to the advanced computing technologies and the obvious convenience over the traditional mail-based surveys. In addition, a study reported that web-based surveys are effective in terms of the response rate [51].

Questionnaires were distributed mainly to supply chain managers of 1090 manufacturing companies. The list of sample firms and their supply chain managers were obtained from the Korean Logistic Association and the Korea Auto Industries Coop Association database. Another list of firms was obtained from a large original equipment manufacturer (OEM) in Korea. To increase the response rate, this study followed a strategy suggested by Dillman [52]. Initial e-mailing was followed by reminder e-mails after two weeks. Out of 1090 emails, 240 had incorrect information and the emails were returned with the deliveryerror message. The survey yielded 202 usable responses (a response rate of $23.76 \%$ ), which is an acceptable rate for an SCM survey [53]. Table 1 shows the sample characteristics in terms of the industry type and size of the participating organizations. 
Table 1. Sample characteristics.

\begin{tabular}{ccc}
\hline Industry Type & Frequency & Percent \\
\hline $\begin{array}{c}\text { Automobile hardware and manufacturing } \\
\text { Industrial, commercial machinery and computer } \\
\text { equipment }\end{array}$ & 54 & 26.7 \\
\hline Metal manufacturing & 41 & 20.3 \\
\hline $\begin{array}{c}\text { Rubber and miscellaneous plastics products } \\
\text { Electronic/other electrical equipment and } \\
\text { components, except computers }\end{array}$ & 31 & 15.3 \\
\hline Logistics & 29 & 14.4 \\
\hline Miscellaneous manufacturing industries & 5 & 11.4 \\
\hline Total & 2 & 1.5 \\
\hline Number of Employees & 202 & 100.0 \\
\hline Up to 50 & Frequency & Percent \\
\hline $51-100$ & 2 & 1.0 \\
\hline $101-150$ & 10 & 5.0 \\
\hline $151-200$ & 51 & 29.2 \\
\hline $201-250$ & 30 & 14.9 \\
\hline $251-300$ & 59 & 29.2 \\
\hline Over 300 & 37 & 18.3 \\
\hline Total & 13 & 6.4 \\
\hline
\end{tabular}

\section{Results}

\subsection{Measurement Model}

Structural equation modeling (SEM) with AMOS 26.0 was used to test and analyze the hypothesized relationships in the research model. The main reason that SEM is widely employed in many scientific fields is that it can explicitly take into account measurement errors in the observed variables (both dependent and independent) [54,55]. In this study, we analyzed the collected data to establish dimensional structures. First, the content validity was tested to assure that the measures used adequately represented all facets of the concepts. Confirmatory factor analysis (CFA) was conducted to establish the convergent and discriminant validity. The overall model fit was assessed using the indices of various fit criteria (RMSEA = 0.078; CFI = 0.909; CMIN/DF = 2.233) [56-61].

The convergent validity was assessed by the item factor loadings and the squared multiple correlation coefficients of the items. Convergent validity is the degree to which scores on a test correlate with scores on other tests designed for assessing the same construct [62]. Fornell and Larcker [63] suggested that convergent validity exists when the item factor loadings are greater than 0.7 and items' squared multiple correlation coefficients are greater than 0.5 (See Table 2). RG 2 and GP 5 were dropped due to their small loadings.

To assess the reliability of the constructs, composite reliability (CR) was used. Reliability refers to the relative absence of measurement errors, regardless of the time, form, questionnaire items, researcher, and subject group of the study. It also represents the extent to which a test or other instrument is consistent in its measures. Both the AVE and CR values exceeded the recommended thresholds of 0.5 and 0.6 , respectively [64]. 
Table 2. Construct and reliability.

\begin{tabular}{|c|c|c|c|c|c|}
\hline Construct & Items & Standardized Loading & Standardized Error & Composite Reliability ${ }^{1}$ & $\mathrm{AVE}^{2}$ \\
\hline \multirow{4}{*}{$\begin{array}{l}\text { Transactional } \\
\text { governance }\end{array}$} & TG1 & 0.733 & 0.269 & \multirow{4}{*}{0.905} & \multirow{4}{*}{0.706} \\
\hline & TG2 & 0.783 & 0.238 & & \\
\hline & TG3 & 0.772 & 0.261 & & \\
\hline & TG4 & 0.803 & 0.224 & & \\
\hline \multirow{6}{*}{$\begin{array}{l}\text { Relational } \\
\text { governance }\end{array}$} & RG1 & 0.864 & 0.289 & \multirow{6}{*}{0.946} & \multirow{6}{*}{0.779} \\
\hline & RG2 & De & & & \\
\hline & RG3 & 0.875 & 0.301 & & \\
\hline & RG4 & 0.931 & 0.180 & & \\
\hline & RG5 & 0.938 & 0.141 & & \\
\hline & RG6 & 0.905 & 0.242 & & \\
\hline \multirow{6}{*}{ Trust } & TS1 & 0.89 & 0.278 & \multirow{6}{*}{0.947} & \multirow{6}{*}{0.751} \\
\hline & TS2 & 0.891 & 0.257 & & \\
\hline & TS3 & 0.893 & 0.301 & & \\
\hline & TS4 & 0.906 & 0.218 & & \\
\hline & TS5 & 0.936 & 0.186 & & \\
\hline & TS6 & 0.852 & 0.346 & & \\
\hline \multirow{4}{*}{$\begin{array}{l}\text { Exchange } \\
\text { hazard }\end{array}$} & EH 1 & 0.794 & 0.265 & \multirow{4}{*}{0.918} & \multirow{4}{*}{0.739} \\
\hline & EH 2 & 0.803 & 0.336 & & \\
\hline & EH 3 & 0.876 & 0.240 & & \\
\hline & EH 4 & 0.899 & 0.164 & & \\
\hline \multirow{5}{*}{$\begin{array}{l}\text { Green product } \\
\text { innovation }\end{array}$} & GI 1 & 0.874 & 0.212 & \multirow{5}{*}{0.929} & \multirow{5}{*}{0.724} \\
\hline & GI 2 & 0.884 & 0.290 & & \\
\hline & GI 3 & 0.882 & 0.290 & & \\
\hline & GI 4 & 0.851 & 0.354 & & \\
\hline & GI 5 & 0.847 & 0.285 & & \\
\hline \multirow{5}{*}{ Green process } & GP 1 & 0.691 & 0.225 & \multirow{5}{*}{0.920} & \multirow{5}{*}{0.745} \\
\hline & GP 2 & 0.865 & 0.172 & & \\
\hline & GP 3 & 0.854 & 0.187 & & \\
\hline & GP 4 & 0.753 & 0.278 & & \\
\hline & GP 5 & De & & & \\
\hline \multirow{5}{*}{$\begin{array}{l}\text { Environmental } \\
\text { performance }\end{array}$} & Evnp1 & 0.816 & 0.229 & \multirow{5}{*}{0.939} & \multirow{5}{*}{0.757} \\
\hline & Envp2 & 0.824 & 0.274 & & \\
\hline & Envp3 & 0.908 & 0.128 & & \\
\hline & Envp4 & 0.812 & 0.241 & & \\
\hline & Envp5 & 0.800 & 0.241 & & \\
\hline \multirow{4}{*}{$\begin{array}{c}\text { Financial } \\
\text { performance }\end{array}$} & Finp 1 & 0.864 & 0.287 & \multirow{4}{*}{0.934} & \multirow{4}{*}{0.780} \\
\hline & Finp2 & 0.924 & 0.156 & & \\
\hline & Finp 3 & 0.937 & 0.157 & & \\
\hline & Finp 4 & 0.852 & 0.299 & & \\
\hline
\end{tabular}

The discriminant validity was assessed by comparing the average variance extracted (AVE) with the squared correlation between the constructs [63]. Table 3 shows the correlation coefficients between the latent variables, and the AVE of each construct is shown on the diagonal. Fornell and Larcker [65] stated that the squared correlation between constructs must be less than the AVE of each underlying construct in order for the constructs to have discriminant validity. In this study, every squared correlation between the constructs was greater than the AVE of the constructs. Thus, discriminant validity was assured (see Table 3). 
Table 3. Descriptive statistics and correlations matrix.

\begin{tabular}{|c|c|c|c|c|c|c|c|c|c|c|}
\hline & Mean & SD & 1 & 2 & 3 & 4 & 5 & 6 & 7 & 8 \\
\hline $\begin{array}{l}\text { Transactional } \\
\text { governance (1) }\end{array}$ & 4.887 & 0.663 & 0.707 & & & & & & & \\
\hline $\begin{array}{c}\text { Relational } \\
\text { governance (2) }\end{array}$ & 4.272 & 1.033 & $-0.141 *$ & 0.780 & & & & & & \\
\hline Trust (3) & 4.336 & 1.054 & $-0.189 *$ & $0.712 * *$ & 0.751 & & & & & \\
\hline Exchange hazard (4) & 5.011 & 0.837 & $0.651^{* *}$ & -0.090 & -0.038 & 0.739 & & & & \\
\hline Green innovation (5) & 4.675 & 0.973 & $-0.150 *$ & $0.562^{* *}$ & $0.579 * *$ & -0.141 * & 0.725 & & & \\
\hline Green process (6) & 5.355 & 0.658 & $0.180 *$ & $0.247^{* *}$ & 0.097 & 0.085 & $0.160 *$ & 0.745 & & \\
\hline $\begin{array}{l}\text { Environmental } \\
\text { performance (7) }\end{array}$ & 5.385 & 0.745 & 0.019 & $0.367^{* *}$ & $0.201^{* *}$ & -0.010 & $0.341^{* *}$ & $0.612 * *$ & 0.757 & \\
\hline $\begin{array}{c}\text { Financial } \\
\text { performance (8) }\end{array}$ & 4.677 & 0.984 & $0.222 * *$ & 0.452 ** & $0.311^{* *}$ & -0.030 & $0.456^{* *}$ & $0.419 * *$ & $0.477^{* *}$ & 0.781 \\
\hline
\end{tabular}

${ }^{*} p<0.05 ; * * p<0.01$.

\subsection{StrucModel Analysis and Results}

The results of the hypotheses tests and the significance of the links are summarized in Table 3. The firm size was controlled, as it could affect the relationships between the antecedent (i.e., trust and exchange hazard) and supply chain governance, between supply chain governance and GSCM (i.e., green process and green innovation), and between GSCM and the organizational performance. As shown in Table 4, after controlling for firm size, the effect of the exchange hazard on transactional governance was significant and positive $(\gamma=0.691, p<0.01)$. The result provided strong support for Hypothesis 1 . Thus, when a firm experienced an exchange hazard in a relationship, the suppliers and OEMs were more likely to have transactional governance with a more specified contract to regulate the relationship. In the situation where a firm trusted its partner, the interorganizational relationship would be governed by the relational mechanism $(r=0.641, p<0.01)$. This implied that trust between partners mitigates the risk of disruption of the relationship [66] and this result supported Hypothesis 2.

Table 4. Summary of hypotheses.

\begin{tabular}{|c|c|c|c|c|c|c|}
\hline Hypothesis & & Path & & Direct Effects & $p$-Value & $\begin{array}{l}\text { Hypotheses } \\
\text { Testing }\end{array}$ \\
\hline $\mathrm{H} 1$ & Exchange hazard & $\Longrightarrow$ & $\begin{array}{l}\text { Transactional } \\
\text { governance }\end{array}$ & $0.691 * *$ & 0.001 & Supported \\
\hline $\mathrm{H} 2$ & Trust & $\Longrightarrow$ & $\begin{array}{c}\text { Relational } \\
\text { governance }\end{array}$ & $0.641 * *$ & 0.001 & Supported \\
\hline $\mathrm{H} 3 \mathrm{a}$ & $\begin{array}{l}\text { Transactional } \\
\text { governance }\end{array}$ & $\Longrightarrow$ & Green process & $0.238^{* *}$ & 0.003 & Supported \\
\hline $\mathrm{H} 3 \mathrm{~b}$ & $\begin{array}{l}\text { Transactional } \\
\text { governance }\end{array}$ & $\Longrightarrow$ & Green innovation & -0.054 & 0.397 & Not supported \\
\hline $\mathrm{H} 4 \mathrm{a}$ & $\begin{array}{c}\text { Relational } \\
\text { governance }\end{array}$ & $\Longrightarrow$ & Green innovation & $0.424 * *$ & 0.001 & Supported \\
\hline $\mathrm{H} 4 \mathrm{~b}$ & $\begin{array}{c}\text { Relational } \\
\text { governance }\end{array}$ & $\Longrightarrow$ & Green process & $0.315^{* *}$ & 0.001 & Supported \\
\hline H5a & Green process & $\Longrightarrow$ & $\begin{array}{c}\text { Financial } \\
\text { performance }\end{array}$ & $0.379 * *$ & 0.001 & Supported \\
\hline $\mathrm{H} 5 \mathrm{~b}$ & Green process & $\Longrightarrow$ & $\begin{array}{c}\text { Environmental } \\
\text { performance }\end{array}$ & $0.586 * *$ & 0.001 & Supported \\
\hline H6a & Green innovation & $\Longrightarrow$ & $\begin{array}{c}\text { Financial } \\
\text { performance }\end{array}$ & $0.481 * *$ & 0.001 & Supported \\
\hline $\mathrm{H} 6 \mathrm{~b}$ & Green innovation & $\Longrightarrow$ & $\begin{array}{l}\text { Environmetnal } \\
\text { performance }\end{array}$ & $0.171 *$ & 0.015 & Supported \\
\hline
\end{tabular}


The transactional governance mechanism exhibited a high level of green process $(\mathrm{r}=0.238, p<0.01)$, while it did not affect green innovation $(\mathrm{r}=-0.54, p>0.05)$. Thus, Hypothesis $3 a$ was supported but Hypothesis $3 b$ was not. The relational governance mechanism significantly affected both green process $(r=0.315, p<0.01)$ and green innovation $(\mathrm{r}=0.424, p<0.01)$. The paths from green process to environmental performance $(\gamma=0.481$, $p<0.01)$ and to financial performance $(\gamma=0.379, p<0.01)$ were significant. Therefore, Hypotheses $5 \mathrm{a}$ and $5 \mathrm{~b}$ were also supported. The paths from green innovation to financial performance $(\gamma=0.481, p<0.01)$ and to environmental performance $(\gamma=0.171, p<0.05)$ were significant, supporting both Hypotheses $6 \mathrm{a}$ and $6 \mathrm{~b}$.

\subsection{Discussion of Hypotheses Testing Results}

The SEM analysis supported the positive impact of exchange hazard on the transactional governance $(r=0.691)$ mechanism and of trust on the relational governance mechanism $(r=641)$. This implied that interorganizational transaction experiences (i.e., exchange hazard and trust) decide the forms or structures of the interorganizational relationship [67]. These results were consistent with previous findings. Mesquita and Brush [68] argued that to reduce the hazard in OEMs-suppliers relationships, transactional governance mechanisms can be implemented as safeguards or as a coordination device. The literature has identified that the trust of the supplier, relational capital, and commitment exert significant effects on the structure of the relationship [20,69]. When partner firms trust each other, their willingness to maintain a long-term relationship constitutes the relational governance mechanism.

An interesting finding from this study was that different governance mechanisms have different impacts on GSCM. In this study, GSCM was measured by two different constructs, the green process and green innovation. The green process, which is a function or system of green operations, does not require extensive knowledge exchange [70]. Thus, both governance mechanisms affected the green process positively. While both governance mechanisms affected the green process significantly, relational governance had a stronger relationship $(r=0.315)$ with the green process as compared to the transactional governance mechanism $(r=0.238)$. In addition, green innovation was affected by relational governance $(\mathrm{r}=0.424)$ but not by transactional governance $(\mathrm{r}=-0.54)$. These results were consistent with those of previous studies [36]. Previous studies have argued that relational mechanisms have positive impacts on knowledge creation [71]. To increase the capability for innovating green-related products, knowledge exchange or building knowledge-sharing routines between organizations is necessary [72]. Panayides \& Venus Lun [73] maintained that trust between firms facilitates innovation from the OEMs-suppliers relationship. The transactional governance mechanism is not effective in encouraging partners to get involved in knowledge-creation projects. Since transactional governance is derived from the exchange hazard, participating firms may hesitate to provide their capabilities that are not listed on the contract. However, when firms trust each other and operate under a sound relational mechanism, they are willing to share even the knowledge that is not specified on the contract. Consistent with the literature, the green process was affected by two governance mechanisms. Since the green process is like an asset-based resource or infrastructure of a firm, it can be easily monitored using the transactional governance mechanism [74]. Furthermore, as has been suggested by previous studies [75], the relational governance mechanism motivates partners to participate in the project or strategy initiated by OEMs.

Two GSCM constructs, green process and green innovation, positively affect organizational performance. It has been argued that GSCM positively affects organizational performance [76]. However, the results of this study indicated there are different relationship strengths depending on the type of GSCM. Since the green process is a function or system that has an immediate impact on green performance, the green process has a stronger relationship with environmental performance $(r=-0.481)$ than with green innovation $(r=0.171)$. On the other hand, green innovation, which is more of a value- 
creating activity, has a greater impact on financial performance $(r=0.481)$ than on the green process $(r=0.379)$. Thus, this study found that green innovation is effective in improving financial performance, while the green process was identified as a practical strategy for improving environmental performance. Since there has been no study that has included both green innovation and the green process, it is not easy to compare the results of our study with the literature. However, these results can be explained based on the results reported by Zhu and Sarkis [77]. Their study found that eco-design is more positively related to financial performance than to internal or external environmental practices, and internal and external environmental practices are more positively related to environmental performance than eco-design is to environmental performance. Since eco-design refers to managing suppliers' control of the design process for products, it is comparable to green innovation. Furthermore, internal and external environmental practices can be equivalent to the green process in this study, because their measurements are similar.

\section{Discussion and Conclusions}

In today's digital era, corporate environmental strategies have moved beyond reactive approaches to focusing on internal functions. Now, firms take more proactive approaches to engaging with business partners (i.e., suppliers). However, most previous GSCM related studies have not investigated which governance mechanisms of the inter-organizational relationship can lead to successful GSCM. This study focused on two GSCM practices, green innovation and the green process, and proposed two governance mechanisms, transactional and relational, for successful GSCM implementation, which in turn positively affect organizational performance.

This study found evidence that the right choice of governance mechanism in the OEM-supplier relationship depends on the status of their relationship and considered the exchange hazard, the level of potential opportunism, as an antecedent that leads firms to formal contract-based relationships. The results of this study supported the notion that transactional governance encourages suppliers to be involved in GSCM initiated by OEMs. Particularly, the green process, which is one of systems that suppliers need to implement to fulfill the GSCM strategy, is positively related to the transactional governance mechanism. Since green processes can be measured directly by the partners with the transactional governance mechanism, each partner firm can monitor or manage the quality or status of the green process by regulating the internal green management practice with their partners based on a contract. However, the transactional governance mechanism does not positively affect green innovation. Unlike the green process, green innovation requires knowledge exchange between partners. Knowledge exchange, especially of the tacit type, cannot be stipulated by contracts or documents. Thus, the transactional governance mechanism can limit the willingness to be involved in the innovation process beyond what is documented in the contract. This empirical result contributes to the literature by confirming that a specific contract with the supplier can hamper the autonomy of suppliers' innovative capability.

Consistent with the literature on relational governance, this study found that trust is imperative to maintain a relational governance mechanism. The findings from this study supported the major notion of social exchange theory that concerns how transactions in an interorganizational relationship evolve and change over time. As social exchange theory argues, the willingness to accept vulnerability is the cornerstone of the theory. The results of this study showed that trust is a key factor to motivate partners to be involved in the GSCM strategy. Such a committed relationship, based upon mutual trust, usually develops over time. Firms can develop, test, observe, and confirm the existence of trust. According to social exchange theory, partners are willing to participate in the relationship beyond what is necessary according to the contract [78].

Green innovation is increasingly viewed as a key to sustainable product development. Since supply chain partners are highly interdependent, a firm should share information with their partners to successfully manage product development processes. Thus, when 
there is no or limited information exchange between partners in the supply chain, a GSCM project can hardly avoid failure. The environmental impacts of products are usually determined when the raw materials are selected. Managing the suppliers during the early design phase is an essential part of designing environmentally friendly products. In fact, the relational governance mechanism has been recognized as a major collaboration structure in product innovation [79]. Using a collaborative product design, firms can participate in global supply chains and work closely with various partners. Thus, firms can obtain valuable inputs for their product design. Furthermore, firms can track and manage their eco-friendly goods through collaborative relationships. This finding supports previous studies that have argued that new product development can be invigorated by building a close relationship between OEMs and suppliers [80].

The importance of relational governance is also evident in the green process. The green process includes ISO 14001 certification, pollution prevention, recycling of materials, waste reduction, and workplace health and safety. With the ever-increasing environmental concerns and strict regulations, firms strive to manage these activities in a more costeffective and timely manner. According to Gavronski et al. [70], the green process represents the capability that enables the firm to successfully implement GSCM.

This study found that GSCM improves organizational performance, which is measured in both financial and environmental terms. This study provides compelling evidence that collaboration between supply chain partners through an effective governance mechanism is necessary to implement successful GSCM.

Overall, this study contributes to the growing body of research on the business value of green strategies by highlighting the role of the supply chain governance mechanism. As discussed earlier, previous studies that examined the effects of GSCM practices have underscored the need for an effective governance mechanism for GSCM. Some studies have argued for the importance of collaboration with external partners. However, there is a paucity of research on the type of collaboration for GSCM that is best suited to a given relationship status. The findings of this study suggest that mangers should carefully assess the particulars of their current relationship and try to develop trust with partners, because a firm can only successfully implement green innovation through a relational governance mechanism. However, the transactional governance mechanism also contributes to organizational performance by improving the green process more effectively than the relational governance mechanism. Thus, managers should understand the importance of implementing the right governance mechanism for a given situation.

\section{Limitations and Future Research Directions}

This study investigated the role of the supply chain governance mechanism for suppliers to successfully implement GSCM. While this paper's results make new contributions to the GSCM literature, there were several limitations to the study. Firstly, since this study was based on cross-sectional data, it was impossible to understand the effect of the time lag between the constructs. As discussed earlier, if the relationship between green innovation and organizational performance can be analyzed while considering the time lag, it might yield interesting new insights.

Secondly, the relationship between two governance mechanisms was not studied in this paper. Firms may start a relationship with a transactional governance mechanism and gradually develop to relational governance later [81]. Ness and Haugland [82] examined the evolution of relational governance and transactional governance in interorganizational relationships. They argued that some firms could begin a relationship with transactional governance and later develop it into a relational governance mechanism. Additionally, just like ambidextrous capability, by employing the transactional governance mechanism and relational mechanism at the same time, a firm might be able to focus not only on its current competitive advantage, but also on its long-term competitiveness.

Finally, due to the relatively small sample size, some of the fit indices were not as good as would be desired. A larger sample size would have increased the statistical power and 
given better results. Furthermore, since data were collected from a single source, common methods bias could be a problem. For this study, financial performance was measured based on the respondents' self-perception, not by actual financial data. The respondents' self-perception had potential exaggerating effects. The limitations of the study discussed here provide future research opportunities in the fertile field of GSCM.

Author Contributions: Conceptualization, D.C.; methodology, D.C.; validation, S.M.L.; formal analysis, D.C.; investigation D.C.; data curation D.C.; writing-original draft preparation, D.C.; writing-review and editing, S.M.L.; supervision, S.M.L. All authors have read and agreed to the published version of the manuscript.

Institutional Review Board Statement: Not applicable.

Informed Consent Statement: Informed consent was obtained from all subjects involved in the study.

Conflicts of Interest: The authors declare no conflict of interest.

\section{Appendix A}

Table A1. Literature review.

\begin{tabular}{|c|c|c|c|}
\hline Construct & Measurement & Code & Literature \\
\hline \multirow{4}{*}{$\begin{array}{l}\text { Transactional } \\
\text { mechanism }\end{array}$} & $\begin{array}{l}\text { We have formal agreements that detail the obligations and rights of } \\
\text { both parties }\end{array}$ & TG 1 & \multirow{4}{*}{ [20] } \\
\hline & The buyer rarely works with us on the SCC implementation. & TG 2 & \\
\hline & $\begin{array}{l}\text { If we struggle in the SCC, the buyer would simply switch to other } \\
\text { suppliers rather than work out a solution with us. }\end{array}$ & TG 3 & \\
\hline & We have specific, well-designed agreements with buyer & TG 4 & \\
\hline \multirow{6}{*}{$\begin{array}{l}\text { Relational } \\
\text { mechanism }\end{array}$} & $\begin{array}{c}\text { The buyer allows open, two-way dialogue on the SCC issues, so that } \\
\text { the SCC targets can be established jointly. }\end{array}$ & RG 1 & \multirow{6}{*}[83,84]{} \\
\hline & $\begin{array}{l}\text { The buyer works with us closely to implement the SCC (e.g., visiting } \\
\text { our production facilities, providing ongoing training programs, etc.). }\end{array}$ & RG 2 & \\
\hline & $\begin{array}{l}\text { If we comply with the SCC, we would get incentives from the buyer } \\
\text { (e.g., extending or renewing contracts, increasing order volumes, } \\
\text { financial rewards, etc.). }\end{array}$ & RG 3 & \\
\hline & \multirow{3}{*}{$\begin{array}{c}\text { If we struggle in the SCC, the buyer would work out a solution with } \\
\text { us rather than simply switch to other suppliers. } \\
\text { The buyer has invested resources in enabling our capacity. } \\
\text { The buyer and us view each other as partners and share information } \\
\text { very well. }\end{array}$} & RG 4 & \\
\hline & & RG 5 & \\
\hline & & RG 6 & \\
\hline \multirow{6}{*}{ Trust } & We believe in the partner because it is sincere. & TS 1 & \multirow{6}{*}[20,84]{} \\
\hline & The partner and our firm have a high level of mutual trust. & TS 2 & \\
\hline & The partner is well known for fair dealing. & TS 3 & \\
\hline & The partner stands by its word. & TS 4 & \\
\hline & $\begin{array}{l}\text { The partner has always been evenhanded in his or her negotiations } \\
\text { with us. }\end{array}$ & TS 5 & \\
\hline & $\begin{array}{c}\text { When making important decisions, the partner is concerned about } \\
\text { our welfare or interests. }\end{array}$ & TS 6 & \\
\hline \multirow{4}{*}{ Exchange hazard } & $\begin{array}{l}\text { We have made substantial investments in personnel dedicated } \\
\text { to partners }\end{array}$ & Eh 1 & \multirow{4}{*}[84,85]{} \\
\hline & $\begin{array}{l}\text { We have made substantial investments in capital equipment and } \\
\text { technology dedicated to partners. }\end{array}$ & Eh 2 & \\
\hline & $\begin{array}{l}\text { This partner sometimes lies about certain things in order to protect } \\
\text { its interests. }\end{array}$ & Eh 3 & \\
\hline & $\begin{array}{l}\text { This partner often fails to deliver promises, as described in } \\
\text { the contract. }\end{array}$ & Eh 4 & \\
\hline
\end{tabular}


Table A1. Cont.

\begin{tabular}{|c|c|c|c|}
\hline Construct & Measurement & Code & Literature \\
\hline \multirow{5}{*}{$\begin{array}{l}\text { Green product } \\
\text { innovation }\end{array}$} & $\begin{array}{l}\text { Our firm and supply chain partners jointly search and acquire new } \\
\text { and relevant knowledge that is related to green products }\end{array}$ & GI 1 & \multirow{5}{*}[77,86]{} \\
\hline & $\begin{array}{l}\text { Our firm and supply chain partners jointly assimilate and apply } \\
\text { relevant knowledge for green products }\end{array}$ & GI 2 & \\
\hline & $\begin{array}{l}\text { Environmental information was shared and exchanged with key } \\
\text { component/material suppliers }\end{array}$ & GI 3 & \\
\hline & $\begin{array}{l}\text { We design our products to avoid or reduce the use of hazardous } \\
\text { products and their manufacturing process }\end{array}$ & GI 4 & \\
\hline & $\begin{array}{c}\text { Key suppliers were involved in design process to integrate } \\
\text { green issue }\end{array}$ & GI 5 & \\
\hline \multirow{5}{*}{ Green process } & ISO 14001 certification & GP 1 & \multirow{5}{*}[70]{} \\
\hline & Pollution prevention. & GP 2 & \\
\hline & Recycling of materials. & GP 3 & \\
\hline & Waste reduction. & GP 4 & \\
\hline & Workplace health and safety. & GP 5 & \\
\hline \multirow{4}{*}{$\begin{array}{l}\text { Financial } \\
\text { performance }\end{array}$} & Our profitability has increased. & Finp 1 & \multirow{4}{*}[77]{} \\
\hline & Our market share has increased. & Finp 2 & \\
\hline & Our sale growth rate has increased. & Finp 3 & \\
\hline & Our earning per share has increased. & Finp 4 & \\
\hline \multirow{5}{*}{$\begin{array}{l}\text { Environmental } \\
\text { performance }\end{array}$} & Our air emission has been reduced. & Envp 1 & \multirow{5}{*}{ [77] } \\
\hline & Our waste water has been reduced. & Envp 2 & \\
\hline & Our solid waste has been reduced. & Envp 3 & \\
\hline & Our energy consumption has been reduced. & Envp 4 & \\
\hline & $\begin{array}{l}\text { Our resources consumed for manufacturing practices has } \\
\text { been reduced. }\end{array}$ & Envp 5 & \\
\hline
\end{tabular}

\section{References}

1. Kumar, A.; Zavadskas, E.K.; Mangla, S.K.; Agrawal, V.; Sharma, K.; Gupta, D. When risks need attention: Adoption of green supply chain initiatives in the pharmaceutical industry. Int. J. Prod. Res. 2019, 57, 3554-3576. [CrossRef]

2. Griffin, M.A.; Grote, G. When is more uncertainty better? A model of uncertainty regulation and effectiveness. Acad. Manag. Rev. 2020, 45, 745-765. [CrossRef]

3. Lai, K.; Wong, C.W.Y. Green logistics management and performance: Some empirical evidence from Chinese manufacturing exporters. Omega 2011, 40, 267-282. [CrossRef]

4. Marhamati, A.; Azizi, I. The impact of green supply chain management on firm competitiveness. Int. J. Supply Chain Manag. 2017, $6,215-223$.

5. Testa, F.; Iraldo, F. Shadows and lights of GSCM (Green Supply Chain Management): Determinants and effects of these practices based on a multi-national study. J. Clean. Prod. 2010, 18, 953-962. [CrossRef]

6. Responsible Busienss Alliance. Responsible Business Alliance Code of Conduct; Responsible Busienss Alliance: Alexandria, VA, USA, 2018.

7. Stekelorum, R.; Laguir, I.; ElBaz, J. Can you hear the Eco? From SME environmental responsibility to social requirements in the supply chain. Technol. Forecast. Soc. Chang. 2020, 158, 120169. [CrossRef]

8. Luthra, S.; Garg, D.; Haleem, A. The impacts of critical success factors for implementing green supply chain management towards sustainability: An empirical investigation of Indian automobile industry. J. Clean. Prod. 2016, 121, 142-158. [CrossRef]

9. Miao, Z.; Cai, S.; Xu, D. Exploring the antecedents of logistics social responsibility: A focus on Chinese firms. Int. J. Prod. Econ. 2012, 140, 18-27. [CrossRef]

10. Sarkis, J. A strategic decision framework for green supply chain management. J. Clean. Prod. 2003, 11, 397-409. [CrossRef]

11. Vanalle, R.M.; Ganga, G.M.D.; Godinho Filho, M.; Lucato, W.C. Green supply chain management: An investigation of pressures, practices, and performance within the Brazilian automotive supply chain. J. Clean. Prod. 2017, 151, 250-259. [CrossRef]

12. Ashenbaum, B. From market to hierarchy: An empirical assessment of a supply chain governance typology. J. Purch. Supply Manag. 2018, 24, 59-67. [CrossRef]

13. Tangpong, C.; Hung, K.T.; Ro, Y.K. The interaction effect of relational norms and agent cooperativeness on opportunism in buyer-supplier relationships. J. Oper. Manag. 2010, 28, 398-414. [CrossRef]

14. Wang, L.; Sheng, S.; Wu, S.; Zhou, K.Z. Government role, governance mechanisms, and foreign partner opportunism in IJVs. J. Bus. Res. 2017, 76, 98-107. [CrossRef]

15. Williamson, O.E. The Economic Intstitutions of Capitalism; Collier MacMillan Publishers: New York, NY, USA, 1985. 
16. Katz, M.L. Vertical Contractual Relations, Handbook of Industrial Organization; Elsevier: New York, NY, USA, 1989.

17. Chen, P.Y.; Chen, K.Y.; Wu, L.Y. The impact of trust and commitment on value creation in asymmetric buyer-seller relationships: The mediation effect of specific asset investments. J. Bus. Ind. Mark. 2017, 32, 457-471. [CrossRef]

18. Raza, S.A. Supply chain coordination under a revenue-sharing contract with corporate social responsibility and partial demand information. Int. J. Prod. Econ. 2018, 205, 1-14. [CrossRef]

19. Huo, B.; Wang, Z.; Tian, Y. The impact of justice on collaborative and opportunistic behaviors in supply chain relationships. Int. J. Prod. Econ. 2016, 177, 12-23. [CrossRef]

20. Gulati, R.; Nickerson, J.A. Interorganizational trust, governance choice, and exchange performance. Organ. Sci. 2008, 19, 688-708. [CrossRef]

21. Huang, M.C.; Chiu, Y.P. Relationship governance mechanisms and collaborative performance: A relational life-cycle perspective. J. Purch. Supply Manag. 2018, 24, 260-273. [CrossRef]

22. Cole, R.; Aitken, J. Selecting suppliers for socially sustainable supply chain management: Post-exchange supplier development activities as pre-selection requirements. Prod. Plan. Control 2019, 30, 1184-1202. [CrossRef]

23. Zhang, T. How do information technology resources facilitate relational and contractual governance in green supply chain management? Sustainability 2019, 11, 3663. [CrossRef]

24. Anand, B.N.; Khanna, T. Do firms learn to create value? The case of alliances. Strateg. Manag. J. 2000, 21, 295-315. [CrossRef]

25. Liu, Y.; Li, Y.; Shi, L.H.; Liu, T. Knowledge transfer in buyer-supplier relationships: The role of transactional and relational governance mechanisms. J. Bus. Res. 2017, 78, 285-293. [CrossRef]

26. Ghassim, B.; Bogers, M. Linking stakeholder engagement to profitability through sustainability-oriented innovation: A quantitative study of the minerals industry. J. Clean. Prod. 2019, 224, 905-919. [CrossRef]

27. Lei, H.; Ha, A.T.L.; Le, P.B. How ethical leadership cultivates radical and incremental innovation: The mediating role of tacit and explicit knowledge sharing. J. Bus. Ind. Mark. 2020, 35, 849-862. [CrossRef]

28. Foss, N.J.; Husted, K.; Michailova, S. Governing knowledge sharing in organizations: Levels of analysis, governance mechanisms, and research directions. J. Manag. Stud. 2010, 47, 455-482. [CrossRef]

29. Lee, G.; Shin, G.; Hwang, D.W.; Kuper, P.; Kang, M. How manufacturers' long-term orientation toward suppliers influences outsourcing performance. Ind. Mark. Manag. 2018, 74, 288-297. [CrossRef]

30. Oparaocha, G.O. Towards building internal social network architecture that drives innovation: A social exchange theory perspective. J. Knowl. Manag. 2016, 20, 534-556. [CrossRef]

31. Choi, D.; Hwang, T. The impact of green supply chain management practices on firm performance: The role of collaborative capability. Oper. Manag. Res. 2015, 8, 69-83. [CrossRef]

32. Cheng, J.-H.; Yeh, C.-H.; Tu, C.-W. Trust and knowledge sharing in green supply chains. Supply Chain Manag. Int. J. 2008, 13, 283-295. [CrossRef]

33. Steensma, H.K. Acquiring technological competencies through inter-organizational collaboration: An organizational learning perspective. J. Eng. Technol. Manag. 1996, 12, 267-286. [CrossRef]

34. Zhu, Q.; Krikke, H.; Caniels, M.C. Supply chain integration: Value creation through managing inter-organizational learning. Int. J. Oper. Prod. Manag. 2018, 38, 372. [CrossRef]

35. Chaudhuri, A.; Boer, H.; Taran, Y. Supply chain integration, risk management and manufacturing flexibility. Int. J. Oper. Prod. Manag. 2018, 38, 690-712. [CrossRef]

36. Mahapatra, S.K.; Narasimhan, R.; Barbieri, P. Strategic interdependence, governance effectiveness and supplier performance: A dyadic case study investigation and theory development. J. Oper. Manag. 2010, 28, 537-552. [CrossRef]

37. Parkhe, A. Strategic alliance structuring: A game theoretic and trans action cost examination of interfirm cooperation. Acad. Manag. J. 1993, 36, 794-829.

38. Choi, T.Y.; Hartley, J.L. An exploration of supplier selection practices across the supply chain. J. Oper. Manag. 1996, 14, 333-343. [CrossRef]

39. Florida, R. Lean and Green: The move to environmentally conscious manufacturing. Calif. Manag. Rev. 1996, 39, 80-105. [CrossRef]

40. Florida, R.; Davison, D. Gaining from green management. Calif. Manag. Rev. 2001, 43, 63-84. [CrossRef]

41. Longoni, A.; Cagliano, R. Inclusive environmental disclosure practices and firm performance. Int. J. Oper. Prod. Manag. 2018, 38, 1815-1835. [CrossRef]

42. Schmidheiny, S. Changing Course: A Global Business Perspective on Development and the Environment; The MIT Press: Boston, MA, USA, 1992.

43. Walley, N.; Whitehead, B. It's not easy being green. Harv. Bus. Rev. 1994, 72, 46-51.

44. Porter, M.E. What Is Strategy? Harvard Business Review; Harvard Business School Publication Corp: Brighton, MA, USA, 1996.

45. Treacy, R.; Humphreys, P.; McIvor, R.; Lo, C. ISO14001 certification and operating performance: A practice-based view. Int. J. Prod. Econ. 2019, 208, 319-328. [CrossRef]

46. Tsoulfas, G.T.; Pappis, C.P. A model for supply chains environmental performance analysis and decision making. J. Clean. Prod. 2008, 16, 1647-1657. [CrossRef]

47. Lee, S.M.; Noh, Y.; Choi, D.; Rha, J.S. The effect of ISO 14001 on equity structure. Ind. Manag. Data Syst. 2014, 114, 979-991. [CrossRef] 
48. Chen, C.-C. Incorporating green purchasing into the frame of ISO 14000. J. Clean. Prod. 2005, 13, 927-933. [CrossRef]

49. Chen, Y.-S.; Lin, Y.-H.; Lin, C.-Y.; Chang, C.-W. Enhancing green absorptive capacity, green dynamic capacities and green service innovation to improve firm performance: An analysis of structural equation modeling (SEM). Sustainability 2015, 7, 15674-15692. [CrossRef]

50. Brislin, R.W. Back-translation for cross-cultural research. J. Cross-Cult. Psychol. 1970, 1, 185-216. [CrossRef]

51. Boyer, K.K.; Olson, J.R.; Calantone, R.J.; Jackson, E.C. Print versus electronic surveys: A comparison of two data collection methodologies. J. Oper. Manag. 2002, 20, 357-373. [CrossRef]

52. Dillman, D.A. Mail and Internet Surveys: The Tailored Design Method; John Wiley and Sons Inc: New York, NY, USA, 2007.

53. Rosenzweig, E.D.; Roth, A.V.; Dean, J.W. The influence of an integration strategy on competitive capabilities and business performance: An exploratory study of consumer products manufacturers. J. Oper. Manag. 2003, 21, 437-456. [CrossRef]

54. Chin, W.W. Commentary: Issues and opinion on structural equation modeling. MIS Q. 1998, 22, vii-xvi.

55. Kline, R.B. Principles and Practice of Structural Equation Modeling; The Guilford Press: New York, NY, USA, 2010.

56. Bagozzi, R.P.; Yi, Y.; Phillips, L.W. Assessing construct validity in organizational research. Adm. Sci. Q. 1991, 36, 421-458. [CrossRef]

57. Bentler, P.M. Comparative fit indexes in structural models. Psychol. Bull. 1990, 107, 238-246. [CrossRef]

58. Hu, L.; Bentler, P.M. Cutoff criteria for fit indexes in covariance structure analysis: Conventional criteria versus new alternatives. Struct. Equ. Model. A Multidiscip. J. 1999, 6, 1-55. [CrossRef]

59. Jöreskog, K.G. A general approach to confirmatory maximum likelihood factor analysis. Psychometrika 1969, 34, 183-202. [CrossRef]

60. Lance, C.E.; Butts, M.M.; Michels, L.C. The sources of four commonly reported cutoff criteria. Organ. Res. Methods 2006, 9, 202-220. [CrossRef]

61. Shook, C.L.; Ketchen, D.J.; Hult, G.T.M.; Kacmar, K.M. Research notes and commentaries: An assessment of the use of structural equation modeling in strategic management research. Strateg. Manag. J. 2004, 25, 397-404. [CrossRef]

62. Futrell, C.M. Measurement of salespeople's job satisfaction: Convergent and discriminant validity of corresponding INDSALES and job descriptive index scales. J. Mark. Res. 1979, 16, 594-597. [CrossRef]

63. Fornell, C.; Larcker, D.F. Structural equation models with unobservable variables and measurement error: Algebra and statistics. J. Mark. Res. 1981, 18, 382-388. [CrossRef]

64. Shah, R.; Goldstein, S.M. Use of structural equation modeling in operations management research: Looking back and forward. J. Oper. Manag. 2006, 24, 148-169. [CrossRef]

65. Fornell, C.; Larcker, D.F. Evaluating structural equation models with unobservable variables and measurement error. J. Mark. Res. 1981, 18, 39-50. [CrossRef]

66. Braunscheidel, M.J.; Suresh, N.C. The organizational antecedents of a firm's supply chain agility for risk mitigation and response. J. Oper. Manag. 2009, 27, 119-140. [CrossRef]

67. Kwon, I.W.G.; Suh, T. Factors affecting the level of trust and commitment in supply chain relationships. J. Supply Chain Manag. 2004, 40, 4-14. [CrossRef]

68. Mesquita, L.F.; Brush, T.H. untangling safeguard and production coordination effects in long-term buyer-supplier relationships. Acad. Manag. J. 2008, 51, 785-807.

69. Hill, J.A.; Eckerd, S.; Wilson, D.; Greer, B. The effect of unethical behavior on trust in a buyer-supplier relationship: The mediating role of psychological contract violation. J. Oper. Manag. 2009, 27, 281-293. [CrossRef]

70. Gavronski, I.; Klassen, R.D.; Vachon, S.; Nascimento, L.F.M. A resource-based view of green supply management. Transp. Res. Part E Logist. Transp. Rev. 2011, 47, 872-885. [CrossRef]

71. Cao, M.; Zhang, Q. Supply chain collaboration: Impact on collaborative advantage and firm performance. J. Oper. Manag. 2011, 29, 163-180. [CrossRef]

72. Edmondson, A.C.; Bohmer, R.M.; Pisano, G. Disrupted routines: Effects of team learning on new technology adaptation. Adm. Sci. Q. 2001, 46, 685-716. [CrossRef]

73. Panayides, P.M.; Venus Lun, Y.H. The impact of trust on innovativeness and supply chain performance. Int. J. Prod. Econ. 2009, 122, 35-46. [CrossRef]

74. Vivek, D.S.; Banwet, D.K.; Shankar, R. Analysis of interactions among core, transaction and relationship-specific investments: The case of offshoring. J. Oper. Manag. 2008, 26, 180-197. [CrossRef]

75. Claro, D.P.; Hagelaar, G.; Omta, O. The determinants of relational governance and performance: How to manage business relationships? Ind. Mark. Manag. 2003, 32, 703-716. [CrossRef]

76. Lee, S.M.; Noh, Y.; Choi, D.; Rha, J.S. Environmental policy performances for sustainable development: From the perspective of ISO 14001 certification. Corp. Soc. Responsib. Env. Manag. 2017, 24, 108-120. [CrossRef]

77. Zhu, Q.; Sarkis, J. Relationships between operational practices and performance among early adopters of green supply chain management practices in Chinese manufacturing enterprises. J. Oper. Manag. 2004, 22, 265-289. [CrossRef]

78. Azar, A.; Zarakani, M.; Mirhosseini, S.S.; Masouleh, M.H. The mediation role of social capital in relationship between buyersupplier relationship with green supply chain collaboration. Int. J. Logist. Syst. Manag. 2018, 29, 82-101. [CrossRef]

79. Capaldo, A. Network structure and innovation: The leveraging of a dual network as a distinctive relational capability. Strateg. Manag. J. 2007, 28, 585-608. [CrossRef] 
80. Mishra, A.A.; Shah, R. In union lies strength: Collaborative competence in new product development and its performance effects. J. Oper. Manag. 2009, 27, 324-338. [CrossRef]

81. Hoyt, J.; Huq, F. From arms-length to collaborative relationships in the supply chain: An evolutionary process. Int. J. Phys. Distrib. Logist. Manag. 2000, 30, 750-764. [CrossRef]

82. Ness, H.; Haugland, S.A. The evolution of governance mechanisms and negotiation strategies in fixed-duration interfirm relationships. J. Bus. Res. 2005, 58, 1226-1239. [CrossRef]

83. Jiang, B. The effects of interorganizational governance on supplier's compliance with SCC: An empirical examination of compliant and non-compliant suppliers. J. Oper. Manag. 2009, 27, 267-280. [CrossRef]

84. Handley, S.M.; Benton, W., Jr. The influence of exchange hazards and power on opportunism in outsourcing relationships. J. Oper. Manag. 2011, 30, 55-68. [CrossRef]

85. Poppo, L.; Zenger, T. Do formal contracts and relational governance function as substitutes or complements? Strateg. Manag. J. 2002, 23, 707-725. [CrossRef]

86. Johnson, J.L.; Sohi, R.S. The development of interfirm partnering competence: Platforms for learning, learning activities, and consequences of learning. J. Bus. Res. 2003, 56, 757-766. [CrossRef] 